\title{
Development of fluconazole resistance in a series of Candida parapsilosis isolates from a persistent candidemia patient with prolonged antifungal therapy
}

\author{
Li Zhang ${ }^{1,2}$, Meng Xiao ${ }^{1}$, Matthew R. Watts ${ }^{3}$, He Wang ${ }^{1}$, Xin Fan ${ }^{1,2}$, Fanrong Kong ${ }^{3}$ and Ying-Chun X ${ }^{1 *}$
}

\begin{abstract}
Background: Candida parapsilosis was the most common species causing candidemia in the 2010 China Hospital Invasive Fungal Surveillance Net (CHIF-NET) database. Compared to Candida albicans, the description of azole resistance and mechanisms in C. parapsilosis is very limited. We report a patient with C. parapsilosis candidemia over several months, due to a probable intravascular source, who developed fluconazole resistance after prolonged treatment.

Case presentation: An 82 year-old male had a hospital admission of approximately 1.5 years duration. He was initially admitted with acute pancreatitis. Prior to succumbing to the illness, he developed candidemia and treated with three antifungal drugs for nearly 5 months, at suboptimal doses and without source control. Following treatment, 6 blood cultures were still positive for C. parapsilosis. The last 2 strains were resistant to fluconazole (MICs $32 \mu \mathrm{g} / \mathrm{mL}$ ) and intermediate to voriconazole (MICs $0.5 \mu \mathrm{g} / \mathrm{mL}$ ). Microsatellite multilocus analysis indicated that the 6 isolates from the patient belonged to a single genotype. The first 4 isolates were susceptible to fluconazole (MICs $2 \mu \mathrm{g} / \mathrm{mL}$ ) and voriconazole (MICs $0.015-0.03 \mu \mathrm{g} / \mathrm{mL}$ ), which were slightly higher than susceptible control strains from other patients. Overexpression of MDR1 genes were detected in the two resistant isolates, and this was associated with a homozygous mutation in MRR1 genes (T2957C /T2957C), with the amino acid exchange L986P.
\end{abstract}

Conclusions: This case corroborates that the resistant C. parapsilosis isolates can emerge in the setting of complicated infections and the extensive use of antifungal agents, emphasizing the need for standardizing and improving the antifungal treatment as well as source control in the treatment of infection diseases.

Keywords: Candida parapsilosis, Fluconazole resistance, Persistent candidemia, Antifungal treatment, MDR1, MRR1

\section{Background}

Candida parapsilosis is a significant clinical pathogen that can grow in total parenteral nutrition, form biofilms on catheters and other implanted devices, persist in the hospital environment and be nosocomially transmitted by hand carriage [1-4]. In China, C. parapsilosis was the most common species causing candidemia in the 2010 China Hospital Invasive Fungal Surveillance Net (CHIFNET) study [5].

\footnotetext{
* Correspondence: xycpumch@139.com

${ }^{1}$ Department of Clinical Laboratory, Peking Union Medical College Hospital, Chinese Academy of Medical Sciences, Beijing 100730, China

Full list of author information is available at the end of the article
}

Azoles are the most commonly used drugs for the treatment of Candida infections. Besides species that show intrinsic resistance, such as Candida krusei, the acquisition of azole resistance, particularly after prolonged exposure and prophylactic overuse, is well described in Candida albicans, Candida tropicalis, Candida glabrata [6-9]. However, the descriptions of azole resistance in $C$. parapsilosis are very limited $[10,11]$.

Constitutive overexpression of 2 types of multidrug efflux pumps, encoded by CDR1 or MDR1 genes is a major cause of resistance to azoles [12-14]. Morschhäuser et al. found that gain of function mutations in $M R R 1$ genes cause constitutive MDR1 overexpression in

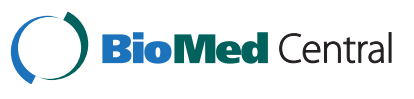

(c) 2015 Zhang et al. Open Access This article is distributed under the terms of the Creative Commons Attribution 4.0 International License (http://creativecommons.org/licenses/by/4.0), which permits unrestricted use, distribution, and reproduction in any medium, provided you give appropriate credit to the original author(s) and the source, provide a link to the Creative Commons license, and indicate if changes were made. The Creative Commons Public Domain Dedication waiver (http://creativecommons.org/publicdomain/zero/1.0/) applies to the data made available in this article, unless otherwise stated. 
fluconazole-resistant $C$. albicans and $C$. dubliniensis [15-17]. Similarly, the mutations in TAC1, a transcription factor regulating $C D R$ genes, are responsible for the constitutive high-level expression of $C D R$ genes $[18,19]$. Another common mechanism is the ERG11 gene overexpression or acquisition of mutations, resulting in target enzyme up-regulation or reduced affinity to bind azoles [12-14]. The mutations in UPC2 are a frequent cause of $E R G$ upregulation [20].

We encountered a case of induced fluconazole resistance in C. parapsilosis from a patient with persistent candidemia due to a probable intravascular source in the Peking Union Medical College Hospital (PUMCH). Here we describe the case and explore the possible resistance mechanism.

\section{Case presentation}

An 82 year-old male was admitted to the PUMCH in December, 2008 with severe, acute pancreatitis. He was managed with mechanical ventilation and received parenteral nutrition, diuretics and anti-microbial therapy. His renal function deteriorated in the $11^{\text {th }}$ week following hospitalization, he began haemodialysis, 3 times per week, through a left internal jugular venous catheter. In the $49^{\text {th }}$ week, he developed a fever of $39^{\circ} \mathrm{C}$, and blood culture were collected. He was treated with empirical meropenem and his fever resolved after 3 days. His blood culture were positive for C. parapsilosis after 7 days, however, due to his clinical improvement he was not given any antifungal therapy (Fig. 1 ). In the $52^{\text {nd }}$ week, the left internal jugular venous catheter was removed, and an arteriovenous fistula was created in the forearm using a polytetrafluoroethylene (PTFE) graft to allow hemodialysis. In the $66^{\text {th }}$ week, he became febrile and a sputum smear showed a large amount of yeast, with culture positive for C. glabrata. CT scan of the chest showed nodules in the right upper lobe and bilateral pleural effusion. He was treated for a pulmonary fungal infection, with fluconazole $(100 \mathrm{mg} /$ day, renal dose adjusted) (Fig. 1). While still on the antifungal therapy, C. parapsilosis susceptible to fluconazole was isolated from blood culture in the $71^{\text {st }}$ week following admission. In the subsequent 9 weeks the patient had intermittent fevers. There were 4 other blood cultures positive for $C$. parapsilosis, consistent with an intravascular source of infection (Fig. 1). The final two isolates (PU123 and PU127) were resistant to fluconazole and had intermediate susceptibility to voriconazole.

Antifungal treatment received by the patient and isolated strains are summarized in Fig. 1. Due to fluconazole treatment failure, it was changed to intraconazole $(100 \mathrm{mg} /$ day $)$ in the $74^{\text {th }}$ week. This was ceased in the $76^{\text {th }}$ week and fluconazole was recommenced at a higher dose $(200 \mathrm{mg} /$ day $)$. As a possible source of infection, the synthetic arteriovenous fistula was removed in the $78^{\text {th }}$ week. However, the candidemia persisted and in the $80^{\text {th }}$ week caspofungin $(50 \mathrm{mg} /$ day $)$ was commenced.

In the $81^{\text {st }}$ week, the patient became comatosed (Glasogow Coma Scale 5) with hypertonia, a positive Babinski sign, and neck rigidity, indicative of central nervous system infection or metabolic encephalopathy. No further investigations were performed, as treatment was withdrawn following discussion with the patient's family. The patient died in the $82^{\text {nd }}$ week of admission.

\section{Comparison with control isolates}

The use of the isolates in the present study was approved by the Human Research Ethics Committee of Peking Union Medical College Hospital (No. S-263). We have obtained the writing consent from the control patients to publish the case report.

There were 6 blood culture isolates from the patient described in the case study (patient 1). In addition, 6 isolates of C. parapsilosis obtained from the other patients (patients 2-7) in the PUMCH during the hospitalization of patient 1 were studied for control purpose. Identification of C. parapsilosis was confirmed by DNA sequencing of the fungal internal transcribed spacer (ITS) region and the D1/D2 domain of the 28S rRNA gene, using a published protocol [5].

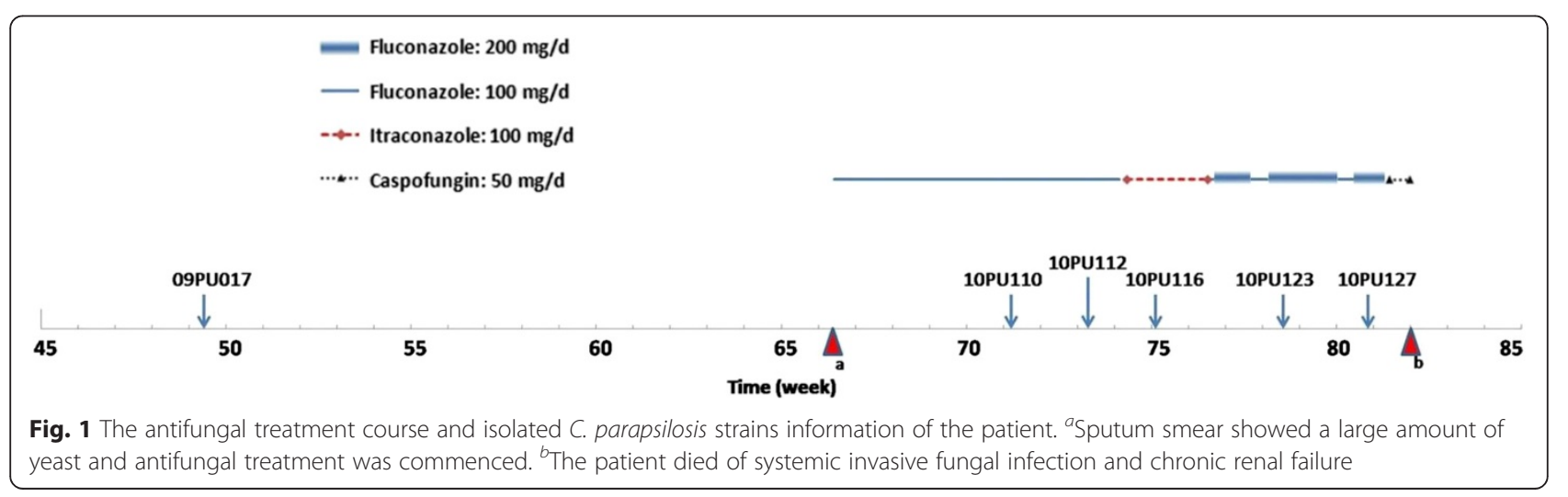


Sensititre YeastOne YO10 broth microdilution susceptibility panels (TREK Diagnostic Systems, Westlake, Ohio) were used to test the susceptibility of C. parapsilosis to antifungal agents, according to a published protocol [21]. For C. parapsilosis, the interpretation of fluconazole, voriconazole and three echinocandins susceptibilities was done in accordance with CLSI M27-S4 [22]. Table 1 summarizes the in vitro susceptibility results of the 12 C. parapsilosis isolates. There was no significant difference in the drugs tested except for fluconazole and voriconazole. The isolates from patients 2-7 were susceptible to fluconazole (MICs $0.25-0.5 \mu \mathrm{g} /$ $\mathrm{mL}$ ) and voriconazole (MICs $\leq 0.008 \mu \mathrm{g} / \mathrm{mL}$ ) (Table 1). For patient 1, isolates PU017, PU110, PU112 and PU116 were susceptible to fluconazole (MICs $2 \mu \mathrm{g} / \mathrm{mL}$ ) and voriconazole (MICs $0.015-0.03 \mu \mathrm{g} / \mathrm{mL}$ ), but with higher MICs than the other susceptible strains. Isolates PU123 and PU127 were resistant to fluconazole (MICs $32 \mu \mathrm{g} /$
$\mathrm{mL}$ ) and had intermediate susceptibility to voriconazole (MICs $0.5 \mu \mathrm{g} / \mathrm{mL}$ ) (Table 1).

All the strains were genotyped using the highly polymorphic microsatellite markers, $\mathrm{B} 5, \mathrm{CP} 1, \mathrm{CP} 4$ and CP6 [23]. Amplification reactions were performed as previously reported [23]. The microsatellite multilocus genotypes allowed the differentiation of the 12 strains from 7 patients into 6 different genotypes. The 6 isolates from patient 1 involved a single genotype (genotype A). The strains isolated from control patients 2-4 and 6, 7 were assigned to genotypes $B$ to $\mathrm{G}$ based on the observed differences. Isolate PU106 from the control patient 5 showed the same pattern on microsatellite sequence analysis as the isolates from patient 1 and designated genotype A (Table 1).

Primers used for PCR amplification of MRR1, TAC1, $U P C 2$, and ERG11 genes were listed in Table 2 (11). After alignment of the MRR1 sequences from the 12

Table 1 C. parapsilosis strains information, antifungal susceptibilities, microsatellite typing results and the MRR1 gene mutations

\begin{tabular}{|c|c|c|c|c|c|c|c|c|c|c|c|c|c|c|c|c|c|}
\hline \multirow[t]{2}{*}{ Strain no. ${ }^{a}$} & \multirow[t]{2}{*}{ Patient } & \multirow[t]{2}{*}{ Ward $^{b}$} & \multicolumn{9}{|c|}{ Susceptibility results by Sensititre YeastOne $(\mu \mathrm{g} / \mathrm{mL})$} & \multicolumn{4}{|c|}{ Multilocus genotype $^{d}$} & \multirow[t]{2}{*}{ Genotype $^{\mathrm{e}}$} & \multirow[t]{2}{*}{ MRR1 } \\
\hline & & & $\overline{F L C}$ & VRC & ITC & POS & ANF & MCF & CAS & $5 F C$ & $\overline{\mathrm{AMB}}$ & $\overline{B 5}$ & CP1 & CP4 & CP6 & & \\
\hline PU017 & 1 & EGW & 2 & 0.03 & 0.12 & 0.06 & 0.5 & 0.5 & 0.25 & 0.06 & 0.5 & $\begin{array}{l}109 / \\
109\end{array}$ & $\begin{array}{l}242 / \\
242\end{array}$ & $\begin{array}{l}307 / \\
307\end{array}$ & $\begin{array}{l}291 / \\
291\end{array}$ & A & $\begin{array}{l}\text { T2957C/ } \\
\text { WT }\end{array}$ \\
\hline PU110 & 1 & EGW & 2 & 0.03 & 0.12 & 0.06 & 0.5 & 0.5 & 0.25 & 0.06 & 0.5 & $\begin{array}{l}109 / \\
109\end{array}$ & $\begin{array}{l}242 / \\
242\end{array}$ & $\begin{array}{l}307 / \\
307\end{array}$ & $\begin{array}{l}291 / \\
291\end{array}$ & A & $\begin{array}{l}\text { T2957C/ } \\
\text { WT }\end{array}$ \\
\hline PU112 & 1 & EGW & 2 & 0.03 & 0.06 & 0.06 & 0.25 & 0.25 & 0.25 & 0.06 & 0.5 & $\begin{array}{l}109 / \\
109\end{array}$ & $\begin{array}{l}242 / \\
242\end{array}$ & $\begin{array}{l}307 / \\
307\end{array}$ & $\begin{array}{l}291 / \\
291\end{array}$ & A & $\begin{array}{l}\text { T2957C/ } \\
\text { WT }\end{array}$ \\
\hline PU116 & 1 & EGW & 2 & 0.03 & 0.06 & 0.06 & 0.5 & 0.5 & 0.25 & 0.06 & 0.5 & $\begin{array}{l}109 / \\
109\end{array}$ & $\begin{array}{l}242 / \\
242\end{array}$ & $\begin{array}{l}307 / \\
307\end{array}$ & $\begin{array}{l}291 / \\
291\end{array}$ & A & $\begin{array}{l}\text { T2957C/ } \\
\text { WT }\end{array}$ \\
\hline PU123 & 1 & EGW & 32 & 0.5 & 0.12 & 0.06 & 0.5 & 0.5 & 0.5 & 0.06 & 0.5 & $\begin{array}{l}109 / \\
109\end{array}$ & $\begin{array}{l}242 / \\
242\end{array}$ & $\begin{array}{l}307 / \\
307\end{array}$ & $\begin{array}{l}291 / \\
291\end{array}$ & A & $\begin{array}{l}\text { T2957C/ } \\
\text { T2957C }\end{array}$ \\
\hline PU127 & 1 & EGW & 32 & 0.5 & 0.12 & 0.06 & 0.5 & 0.5 & 0.5 & 0.06 & 0.5 & $\begin{array}{l}109 / \\
109\end{array}$ & $\begin{array}{l}242 / \\
242\end{array}$ & $\begin{array}{l}307 / \\
307\end{array}$ & $\begin{array}{l}291 / \\
291\end{array}$ & A & $\begin{array}{l}\text { T2957C/ } \\
\text { T2957C }\end{array}$ \\
\hline PU004 & 2 & Outpatient & 0.5 & $\leq 0.008$ & 0.06 & 0.03 & 0.5 & 0.5 & 0.25 & 0.06 & 0.5 & $\begin{array}{l}107 / \\
107\end{array}$ & $\begin{array}{l}242 / \\
242\end{array}$ & $\begin{array}{l}307 / \\
307\end{array}$ & $\begin{array}{l}267 / \\
267\end{array}$ & B & WT/WT \\
\hline PU026 & 3 & ICU & 0.25 & $\leq 0.008$ & 0.03 & 0.03 & 0.5 & 0.5 & 0.25 & 0.06 & 0.5 & $\begin{array}{l}143 / \\
145\end{array}$ & $\begin{array}{l}242 / \\
242\end{array}$ & $\begin{array}{l}304 / \\
304\end{array}$ & $\begin{array}{l}282 / \\
282\end{array}$ & $C$ & WTMT \\
\hline PU090 & 4 & $\begin{array}{l}\text { Medical } \\
\text { ward }\end{array}$ & 0.5 & $\leq 0.008$ & 0.03 & 0.03 & 0.5 & 0.5 & 0.25 & $\leq 0.06$ & 0.5 & $\begin{array}{l}113 / \\
129\end{array}$ & $\begin{array}{l}224 / \\
245\end{array}$ & $\begin{array}{l}358 / \\
358\end{array}$ & $\begin{array}{l}267 / \\
270\end{array}$ & $\mathrm{D}$ & WT/WT \\
\hline PU106 & 5 & $\begin{array}{l}\text { Surgical } \\
\text { ward }\end{array}$ & 0.5 & $\leq 0.008$ & 0.06 & 0.03 & 0.5 & 0.25 & 0.12 & 0.06 & 0.5 & $\begin{array}{l}109 / \\
109\end{array}$ & $\begin{array}{l}242 / \\
242\end{array}$ & $\begin{array}{l}307 / \\
307\end{array}$ & $\begin{array}{l}291 / \\
291\end{array}$ & $A^{f}$ & WT/WT \\
\hline PU108 & 6 & EGW & 0.5 & $\leq 0.008$ & 0.06 & 0.03 & 0.5 & 0.5 & 0.25 & 0.12 & 0.5 & $\begin{array}{l}115 / \\
129\end{array}$ & $\begin{array}{l}242 / \\
248\end{array}$ & $\begin{array}{l}364 / \\
385\end{array}$ & $\begin{array}{l}267 / \\
267\end{array}$ & E & WT/WT \\
\hline PU131 & 7 & $\begin{array}{l}\text { Medical } \\
\text { ward }\end{array}$ & 0.5 & $\leq 0.008$ & 0.03 & 0.015 & 0.5 & 0.5 & 0.25 & 0.12 & 0.5 & $\begin{array}{l}109 / \\
109\end{array}$ & $\begin{array}{l}242 / \\
242\end{array}$ & $\begin{array}{l}307 / \\
307\end{array}$ & $\begin{array}{l}288 / \\
288\end{array}$ & $\mathrm{~F}$ & WT/WT \\
\hline ATCC 22019 & - & - & 1 & 0.015 & 0.12 & 0.03 & 0.5 & 0.5 & 0.25 & 0.12 & 0.5 & $\begin{array}{l}129 / \\
129\end{array}$ & $\begin{array}{l}245 / \\
251\end{array}$ & $\begin{array}{l}304 / \\
304\end{array}$ & $\begin{array}{l}291 / \\
291\end{array}$ & G & WT/WT \\
\hline
\end{tabular}

${ }^{\text {aAll }}$ strains were isolated from blood cultures

${ }^{\mathrm{b}} E G W$ Emergency general ward

${ }^{\mathrm{C}}$ FLC Fluconazole, VRC Voriconazole, ITC Itraconazole, POS Posaconazole, ANF Anidulafungin, MCF, Micafungin, CAS Caspofungin, 5FC 5-Flucytosine, AMB Amphotericin B. Clinical breakpoints for susceptible, intermediate, and resistant for $C$. parapsilosis, respectively, were those of the CLSI M27-S4 for fluconazole ( $\leq 2 / 4 / \geq 8 \mu \mathrm{g} / \mathrm{mL}$ ); and for voriconazole $(\leq 0.125 / 0.25 / \geq 1 \mu \mathrm{g} / \mathrm{mL})$; and for anidulafungin, caspofungin, and micafungin $(\leq 2 / 4 / \geq 8 \mu \mathrm{g} / \mathrm{mL})$

${ }^{\mathrm{d}}$ The numbers indicate the fragment size in base pairs of the different alleles obtained with the listed marker

'The genotype was designated according to the different microsatellite typing results

${ }^{\mathrm{f}}$ The PU106 isolate yielded identical genotype with the isolates from patient 1 
Table 2 Sequences of primers used in genes sequencing

\begin{tabular}{lll}
\hline Primer name & Primer sequence & Reference \\
\hline MRR1-F & 5'-CCCTTTCTTCCGCAGATTTC-3' & 11 \\
MRR1-R & 5'-CGTTGTAAAGATGGCGTGGT-3' & \\
TAC1-F & 5'-AAGAGACCTACAGATAGTGC-3' & \\
TAC1-R & 5'-CTTGAGATGCTGAGACATAT-3' & \\
UPC2-F & 5'-TTCGTGATAGTTTGGTGGTAG-3' & 11 \\
UPC2-R & 5'-TTTCCTCCACCCCTATTGTAG-3' & \\
ERG11-F & 5'-ATGGCATTAGTTGATTTAGCCCT-3' \\
ERG11-R & 5'-TCAGATTACACATGTATCTCTTT-3' \\
\hline
\end{tabular}

isolates, a single nucleotide mutation (T2957C/WT) was detected in PU017, PU110, PU112 and PU116 compared with the MRR1 sequence of C. parapsilosis ATCC 22019 and the control strain with the same pattern on microsatellite typing, PU106 genotype A (Table 1). This mutation results in the replacement of a leucine amino acid residue with a proline (L986P). In the PU123 and PU127 isolates from patient 1 , mutations were found in both alleles (T2957C/T2957C). After alignment of TAC1, $U P C 2$, and ERG11 gene sequences from the 12 isolates, no mutation was found.

Overnight C. parapsilosis cultures were diluted to an optical density at $600 \mathrm{~nm}\left(\mathrm{OD}_{600}\right)$ of 0.2 in YPD medium and then incubated at $35{ }^{\circ} \mathrm{C}$ with shaking at $150 \mathrm{rpm}$ for additional $6 \mathrm{~h}$ to mid-log phase. Total RNA was extracted from isolates grown in YPD medium using the Yeast RNAiso Reagent Kit (TaKaRa, Tokyo, Japan) and reverse transcribed to cDNA using the PrimeScript RT Reagent Kit (TaKaRa, Tokyo, Japan) according to the instructions of the manufacturer. The quantitative realtime RT-PCRs were performed in triplicate using the SsoFast EvaGreen supermix (Bio-Rad, Hercules, CA, USA) on a BioRad CFX96 system. ATCC 22019 were used as the control isolate. The primers used in this study were listed in Table $3[11,24,25]$. The ACT1 gene was used as the endogenous control. The change in fold expression was obtained by calculating $2^{-\Delta \Delta C T}$, and a change of 2.5 times was considered to be overexpressed [26]. The 2 resistant isolates from patient 1 had higher expression levels of MRR1 than the four susceptible isolates from patient 1 (PU123 10.5-fold and PU127 9.5-fold; Fig. 2). The 4 susceptible isolates showed higher expression levels ( $>2.5$ fold) than the controls. The MDR1 expression was further increased in the resistant isolates (PU123 51.0-fold and PU127 39.4-fold). In contrast, the CDR1, UPC2, ERG11 genes expression levels in the 2 azole-resistant isolates were not significantly different from the 4 susceptible isolates from patient 1 and the control isolates.

In order to confirm that only $M R R 1$ and $M D R 1$ genes were overexpressed, we subcultured isolates in the
Table 3 Sequences of primers used in quantitative real-time RT-PCR

\begin{tabular}{|c|c|c|}
\hline Primer name & Primer sequence & Reference \\
\hline MRR1-F & 5'-ACAATGGTCTGAGCAATGAA-3' & 11 \\
\hline MRR1-R & 5'-GGCAATACTGGTGATGGAA-3' & \\
\hline MDR1-F & 5'-TTCGTGATAGTITTGGTGGTAG-3' & 11 \\
\hline MDR1-R & 5'-TGAACCTGGAGTGAATCTTGT-3' & \\
\hline CDR1-F & 5'-GCGTTTGACCATCGGAGTT-3' & 24 \\
\hline CDR1-R & 5'-TACCGCTGTTTGCGAATCT-3' & \\
\hline UPC2-F & 5'-ATTGGAGTGTGGGTATCTTCAT-3' & 11 \\
\hline UPC2-R & 5'-CCTTCGCCTTCTTCAGTTC-3' & \\
\hline ERG11-F & 5'-GGTTTACTTGTGTTTGCTCCT-3' & 11 \\
\hline ERG11-R & 5'-GTCCATAAGATACGGCTGAAC-3' & \\
\hline $\mathrm{ACT} 1-\mathrm{F}$ & 5'-ATGATAGAGTTGAAAGTAGTTTGGTCAATA-3' & 25 \\
\hline$A C T 1-R$ & 5'-ACTACTGCTGAAAGAGAAATTGTTAGAGAC-3' & \\
\hline
\end{tabular}

presence of sub-inhibitory concentrations of fluconazole, and repeated the gene expression studies. Two susceptible isolates (PU017, PU116), the 2 resistant isolates (PU123 and PU127) from patient 1, 3 control isolates (PU090, PU106 and PU131) were subcultured. All the tested isolates and the control strain ATCC 22019 were firstly incubated at $37{ }^{\circ} \mathrm{C}$ for $4 \mathrm{~h}$ in RPMI 1640 (Sigma, USA). Fluconazole was then added at a concentration of $1 / 2$ MIC and the isolates were incubated for an additional $4 \mathrm{~h}$. RNA extraction and the quantitative realtime RT-PCRs were performed as the previous experiment in the present study.

The 2 resistant isolates showed higher expression levels of MRR1 than the other isolates (PU123 3.90-fold and PU127 3.99-fold; Table 4). The MDR1 expression was also obviously increased in the resistant isolates (PU123 9.70-fold and PU127 9.01-fold). Similar to the previous experiment, the CDR1, UPC2, ERG11 genes expression levels in the 2 azole-resistant isolates were not higher than other susceptible isolates.

\section{Discussion}

Compared to other Candida species, C. parapsilosis tends to be associated with higher MICs to echinocandins [27]. Therefore, the development of azole resistant C. parapsilosis has significant clinical implications, as multiazole- and multiechinocandin-resistant isolates would limit available treatment options [10]. In addition, there could be nosocomial transmission of resistant $C$. parapsilosis between vulnerable patient groups [1-4].

Microsatellite genotyping was consistent with fluconazole resistant developing in previously susceptible strains of $C$. parapsilosis. The 2 resistant patient-isolates (PU123 and PU127) overexpressed MRR1 and MDR1. The $M R R 1$ overexpression was highly associated with mutation (T2957C), leading to the amino acid exchange, 


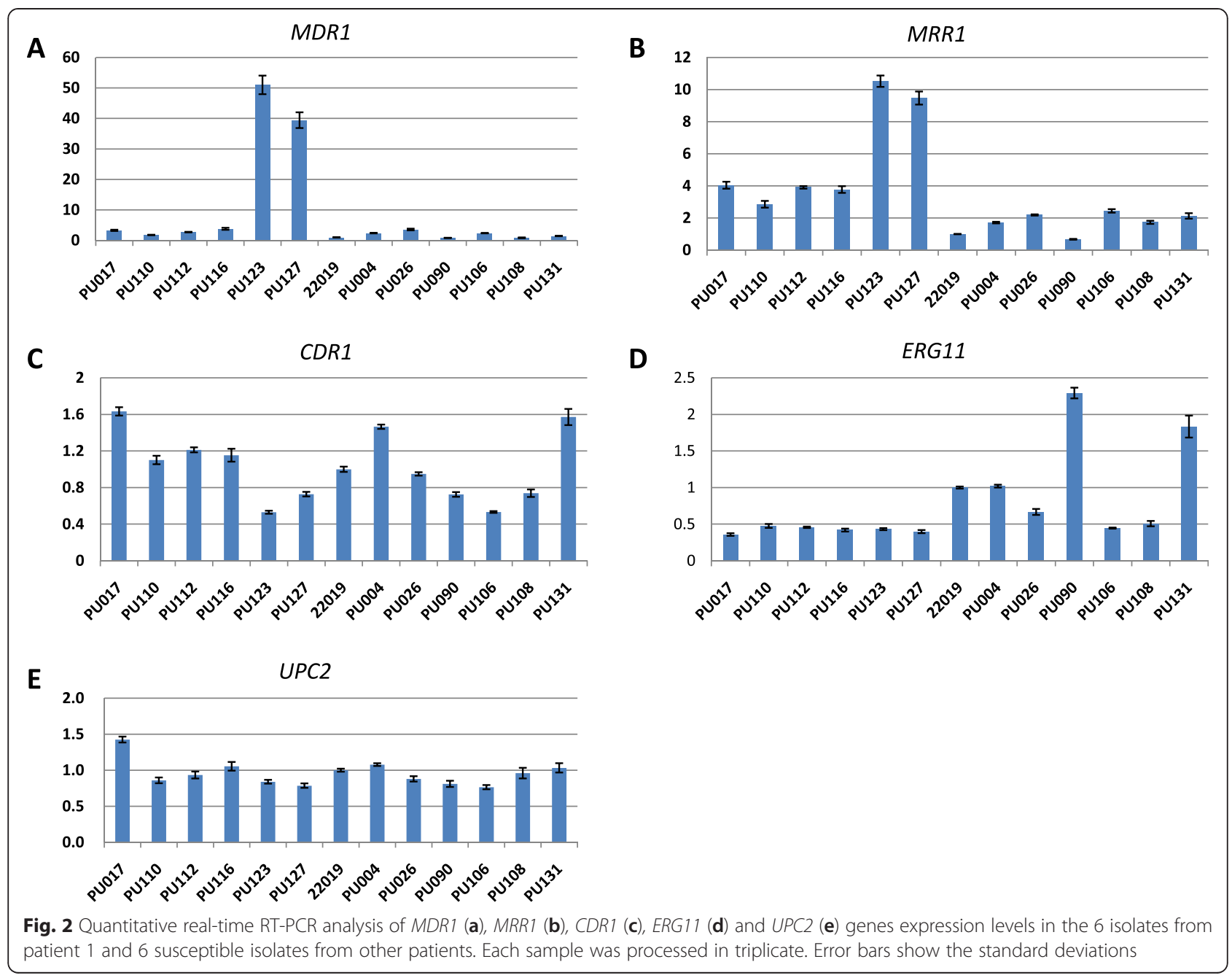

Table 4 Gene expression in the eight C. parapsilosis isolates cultured in the presence of fluconazole with concentrations of $1 / 2$ MIC

\begin{tabular}{|c|c|c|c|c|c|c|c|c|c|c|}
\hline \multirow[t]{2}{*}{ Sample } & \multicolumn{2}{|l|}{$M D R 1^{b}$} & \multicolumn{2}{|l|}{$M R R 1^{b}$} & \multicolumn{2}{|l|}{$C D R 1^{b}$} & \multicolumn{2}{|l|}{$E R G 11^{b}$} & \multicolumn{2}{|l|}{$U P C 2^{b}$} \\
\hline & Expression & $\begin{array}{l}\text { Expression } \\
\text { SEM }\end{array}$ & Expression & $\begin{array}{l}\text { Expression } \\
\text { SEM }\end{array}$ & Expression & $\begin{array}{l}\text { Expression } \\
\text { SEM }\end{array}$ & Expression & $\begin{array}{l}\text { Expression } \\
\text { SEM }\end{array}$ & Expression & $\begin{array}{l}\text { Expression } \\
\text { SEM }\end{array}$ \\
\hline ATCC22019a & 1.00 & 0.04 & 1.00 & 0.03 & 1.00 & 0.02 & 1.00 & 0.04 & 1.00 & 0.03 \\
\hline PU017 & 2.38 & 0.09 & 1.74 & 0.04 & 0.81 & 0.03 & 0.87 & 0.02 & 1.04 & 0.03 \\
\hline PU116 & 2.33 & 0.13 & 1.55 & 0.10 & 1.03 & 0.06 & 1.08 & 0.06 & 1.16 & 0.06 \\
\hline PU123 & 9.70 & 0.63 & 3.90 & 0.20 & 0.21 & 0.01 & 0.26 & 0.15 & 0.31 & 0.02 \\
\hline PU127 & 9.01 & 0.28 & 3.99 & 0.14 & 0.28 & 0.01 & 0.35 & 0.01 & 0.37 & 0.02 \\
\hline PU090 & 2.16 & 0.10 & 0.74 & 0.03 & 0.77 & 0.03 & 0.55 & 0.03 & 0.53 & 0.02 \\
\hline PU106 & 1.45 & 0.07 & 1.55 & 0.05 & 1.55 & 0.04 & 1.13 & 0.05 & 1.86 & 0.07 \\
\hline PU131 & 1.17 & 0.04 & 1.31 & 0.05 & 0.95 & 0.02 & 0.52 & 0.01 & 0.52 & 0.02 \\
\hline
\end{tabular}

${ }^{a}$ ATCC22019 isolates was used as control isolate, and was also cultured in the presence of $1 / 2$ MIC of fluconazole

${ }^{\mathrm{b}}$ All the samples for each gene were tested in triplicate. The left column shows the mean value of expression, and the right column shows the Standard Error of Mean (SEM) 
L986P. This indicates that the C. parapsilosis resistance to fluconazole was conferred by the increased expression of the MRR1 transcription factor, which resulted in a concomitant overexpression of MDR1.

The previous studies have demonstrated that a gainof-function mutation in one MRR1 allele results only in slightly decreased susceptibilities to the azoles and the loss of heterozygosity further increases drug resistance $[15,16]$. A similar observation was made in the present study, where the patient isolates that were heterozygous MRR1 (T2957C/WT) mutants showed slightly higher MICs than wild type strains (WT/WT). The last 2 isolates became homozygous (T2957C/T2957C) mutants and showed much higher MICs and overexpression of MDR1. While this mutation was the probable cause of the phenotypic resistance in this case, a mutagenesis study that demonstrated the development of resistance and increased gene expression in a previously sensitive organism would provide additional evidence.

After repeating the experiment in which the strains were cultured in media containing fluconazole with concentrations of $1 / 2 \mathrm{MIC}$ for each isolate, we confirmed that only $M D R 1$ and $M R R 1$ were overexpressed in 2 resistant isolates. However, MDR1 expression did not increase as much as in the initial experiment. This may be related to different medium as well as all the isolates, including the control isolate ATCC22019, being exposed to fluconazole. The ERG11 genes in resistant isolates were not overexpressed, even following to fluconazole. Similarly, Grossman et al. has sequenced the ERG11 and MRR1 genes in 30 fluconazole resistant C. parapsilosis isolates and 37 susceptible dose-dependent isolates, and found no isolate with both the MRR1 and ERG11 gene mutation [28]. In most cases, phenotypes of resistance developed due to a combination of mechanisms, so the whole genome sequencing will be included in subsequent investigation.

This case corroborates that the resistant C. parapsilosis isolates can emerge in the setting of complicated infections and the extensive use of antifungal agents. Patient 1 received fluconazole treatment for more than 3 months. However, treatment was not instituted for the first candidemia and when fluconazole treatment was commenced it was initially at a lower dose because of chronic renal failure, and on the basis of sputum microscopy. In the previous studies, suboptimal fluconazole dosing has leaded to the development of resistance in Candida species [6, 29]. In addition, itraconazole was used for 2 weeks, when it is not recommended for invasive candidiasis [30]. This highlights the need for standardization of antifungal treatment, in terms of drug selection, dose and duration [31].

In this case, probable sources of the persistent candidemia were the intravenous hemodialysis catheter and the synthetic vascular graft. Vascular catheters have been regarded as the source in more than $50 \%$ of cases of $C$. parapsilosis candidemia and prompt removal of the catheter is recommended [32].

\section{Conclusions}

This report described a case where fluconazole resistant $C$. parapsilosis emerged during prolonged antifungal treatment, with associated MDR1 overexpression, which was related to a MRR1 mutation (T2957C). Resistant $C$. parapsilosis has the potential to complicate the management of candidemia in vulnerable patient groups. This case illustrates the need for effective antifungal treatment, source control in the treatment of infection diseases.

\section{Consent}

Written informed consent was obtained from the patient for publication of this Case report. A copy of the written consent is available for review by the Editor of this journal.

\section{Competing interests \\ The authors declare that they have no competing interests.}

\section{Authors' contributions}

LZ, MX, FK and YCX conceived and designed the experiments; LZ, HW and XF performed the experiment, contributed to the acquisition, analysis and interpretation of data. LZ, MW and FK wrote the manuscript. All authors read and approved the final manuscript.

\section{Acknowledgments}

This present study was supported by Innovation Fund of Peking Union Medical College (2012-1002-023) and Research Special Fund for Public Welfare Industry of Health (201402001). This study was selected for oral presentation at the $12^{\text {th }}$ ASM Conference on Candida and Candidiasis in 2014, New Orleans, America.

\section{Author details}

'Department of Clinical Laboratory, Peking Union Medical College Hospital, Chinese Academy of Medical Sciences, Beijing 100730, China. ${ }^{2}$ Graduate School, Peking Union Medical College, Chinese Academy of Medical Sciences, Beijing 100730, China. ${ }^{3}$ Centre for Infectious Diseases and Microbiology Laboratory Services, ICPMR - Pathology West, University of Sydney, Westmead Hospital, Darcy Road, Westmead, Sydney, NSW 2145 Australia.

Received: 13 December 2014 Accepted: 4 August 2015

Published online: 18 August 2015

\section{References}

1. Trofa D, Gacser A, Nosanchuk JD. Candida parapsilosis, an emerging fungal pathogen. Clin Microbiol Rev. 2008;21(4):606-25.

2. van Asbeck EC, Clemons KV, Stevens DA. Candida parapsilosis: a review of its epidemiology, pathogenesis, clinical aspects, typing and antimicrobial susceptibility. Crit Rev Microbiol. 2009;35(4):283-309.

3. Barchiesi F, Caggiano G, Falconi DFL, Montagna MT, Barbuti S, Scalise G. Outbreak of fungemia due to Candida parapsilosis in a pediatric oncology unit. Diagn Microbiol Infect Dis. 2004;49(4):269-71.

4. Hernandez-Castro R, Arroyo-Escalante S, Carrillo-Casas EM, Moncada-Barron D, Alvarez-Verona E, Hernandez-Delgado L, et al. Outbreak of Candida parapsilosis in a neonatal intensive care unit: a health care workers source. Eur J Pediatr. 2010;169(7):783-7.

5. Wang $H$, Xiao M, Chen SC, Kong F, Sun ZY, Liao K, et al. In vitro susceptibilities of yeast species to fluconazole and voriconazole as 
determined by the 2010 National China Hospital Invasive Fungal Surveillance Net (CHIF-NET) study. J Clin Microbiol. 2012;50(12):3952-9.

6. Andes D, Forrest A, Lepak A, Nett J, Marchillo K, Lincoln L. Impact of antimicrobial dosing regimen on evolution of drug resistance in vivo: fluconazole and Candida albicans. Antimicrob Agents Chemother. 2006;50(7):2374-83.

7. Barchiesi F, Calabrese D, Sanglard D, Falconi DFL, Caselli F, Giannini D, et al Experimental induction of fluconazole resistance in Candida tropicalis ATCC 750. Antimicrob Agents Chemother. 2000;44(6):1578-84.

8. Wingard JR, Merz WG, Rinaldi MG, Johnson TR, Karp JE, Saral R. Increase in Candida krusei infection among patients with bone marrow transplantation and neutropenia treated prophylactically with fluconazole. N Engl J Med. 1991;325(18):1274-7.

9. Wingard JR, Merz WG, Rinaldi MG, Miller CB, Karp JE, Saral R. Association of Torulopsis glabrata infections with fluconazole prophylaxis in neutropenic bone marrow transplant patients. Antimicrob Agents Chemother. 1993;37(9):1847-9.

10. Moudgal V, Little T, Boikov D, Vazquez JA. Multiechinocandin- and multiazole-resistant Candida parapsilosis isolates serially obtained during therapy for prosthetic valve endocarditis. Antimicrob Agents Chemother. 2005;49(2):767-9.

11. Silva AP, Miranda IM, Guida A, Synnott J, Rocha R, Silva R, et al. Transcriptional profiling of azole-resistant Candida parapsilosis strains. Antimicrob Agents Chemother. 2011;55(7):3546-56.

12. Sanglard D, Odds FC. Resistance of Candida species to antifungal agents: molecular mechanisms and clinical consequences. Lancet Infect Dis. 2002;2(2):73-85.

13. Morschhauser J. The genetic basis of fluconazole resistance development in Candida albicans. Biochim Biophys Acta. 2002;1587(2-3):240-8.

14. Pfaller MA. Antifungal drug resistance: mechanisms, epidemiology, and consequences for treatment. Am J Med. 2012;125(1 Suppl):S3-13.

15. Morschhauser J, Barker KS, Liu TT, BlaB-Warmuth J, Homayouni R, Rogers PD. The transcription factor Mrr1p controls expression of the MDR1 efflux pump and mediates multidrug resistance in Candida albicans. PLoS Pathog. 2007;3(11), e164.

16. Dunkel N, Blass J, Rogers PD, Morschhauser J. Mutations in the multi-drug resistance regulator $M R R 1$, followed by loss of heterozygosity, are the main cause of MDR1 overexpression in fluconazole-resistant Candida albicans strains. Mol Microbiol. 2008;69(4):827-40.

17. Schubert S, Rogers PD, Morschhauser J. Gain-of-function mutations in the transcription factor MRR1 are responsible for overexpression of the MDR1 efflux pump in fluconazole-resistant Candida dubliniensis strains. Antimicrob Agents Chemother. 2008;52(12):4274-80.

18. Coste AT, Karababa M, Ischer F, Bille J, Sanglard D. TAC1, transcriptional activator of CDR genes, is a new transcription factor involved in the regulation of Candida albicans $A B C$ transporters CDR1 and CDR2. Eukaryot Cell. 2004;3(6):1639-52.

19. Coste A, Turner V, Ischer F, Morschhauser J, Forche A, Selmecki A, et al. A mutation in Tac1p, a transcription factor regulating CDR1 and CDR2, is coupled with loss of heterozygosity at chromosome 5 to mediate antifungal resistance in Candida albicans. Genetics. 2006;172(4):2139-56.

20. Silver PM, Oliver BG, White TC. Role of Candida albicans transcription factor Upc2p in drug resistance and sterol metabolism. Eukaryot Cell. 2004;3(6):1391-7.

21. Pfaller MA, Chaturvedi V, Diekema DJ, Ghannoum MA, Holliday NM, Killian $\mathrm{SB}$, et al. Clinical Evaluation of the Sensititre YeastOne Colorimetric Antifungal Panel for Antifungal Susceptibility Testing of the Echinocandins Anidulafungin, Caspofungin, and Micafungin. J Clin Microbiol. 2008;46(7):2155-9.

22. Clinical and Laboratory Standards Institute. Reference Method for Broth Dilution Antifungal Susceptibility Testing of Yeasts; Fourth Informational Supplement M27-S4. CLSI, wayne, PA, USA, 2012.

23. Sabino R, Sampaio P, Rosado L, Stevens DA, Clemons KV, Pais C. New polymorphic microsatellite markers able to distinguish among Candida parapsilosis sensu stricto isolates. J Clin Microbiol. 2010;48(5):1677-82.

24. Berkow E, Manigaba K, Wanamaker E, Barker K, Caudle K, Rogers PD. Molecular Mechanisms of Multidrug Resistance in Candida parapsilosis. Poster. the 12th American Society for Microbiology (ASM) Conference, USA, 2014.
25. Rossignol T, Logue ME, Reynolds K, Grenon M, Lowndes NF, Butler G. Transcriptional response of Candida parapsilosis following exposure to farnesol. Antimicrob Agents Chemother. 2007;51(7):2304-12.

26. Jiang C, Dong D, Yu B, Cai G, Wang X, Ji Y, et al. Mechanisms of azole resistance in 52 clinical isolates of Candida tropicalis in China. J Antimicrob Chemother. 2013;68(4):778-85.

27. Perlin DS. Resistance to echinocandin-class antifungal drugs. Drug Resist Updat. 2007;10(3):121-30.

28. Grossman NT, Pham CD, Cleveland AA, Lockhart SR. Molecular Mechanisms of Fluconazole Resistance in Candida parapsilosis Isolates from a U.S. Surveillance System. Antimicrob Agents Chemother. 2015;59(2):1030-7.

29. Shah DN, Yau R, Lasco TM, Weston J, Salazar M, Palmer HR, et al. Impact of prior inappropriate fluconazole dosing on isolation of fluconazole-nonsusceptible Candida species in hospitalized patients with candidemia. Antimicrob Agents Chemother. 2012:56(6):3239-43.

30. Andes D, Pascual A, Marchetti O. Antifungal therapeutic drug monitoring: established and emerging indications. Antimicrob Agents Chemother. 2009;53(1):24-34.

31. Pappas PG, Rex JH, Sobel JD, Filler SG, Dismukes WE. Guidelines for Treatment of Candidiasis. Clin Infect Dis. 2004;38(2):161-89.

32. Pfaller MA, Diekema DJ, Gibbs DL, Newell VA, Ng KP, Colombo A, et al. Geographic and temporal trends in isolation and antifungal susceptibility of Candida parapsilosis: a global assessment from the ARTEMIS DISK Antifungal Surveillance Program, 2001 to 2005. J Clin Microbiol. 2008;46(3):842-9.

\section{Submit your next manuscript to BioMed Central and take full advantage of:}

- Convenient online submission

- Thorough peer review

- No space constraints or color figure charges

- Immediate publication on acceptance

- Inclusion in PubMed, CAS, Scopus and Google Scholar

- Research which is freely available for redistribution 